\title{
PENGEMBANGAN DESAIN PEMBELAJARAN MATA KULIAH PENDIDIKAN MATEMATIKA SD UNTUK TIPE KECERDASAN INTERPERSONAL, NATURALIS, DAN LOGIKA
}

\author{
Tria Mardiana ${ }^{1}$, Septiyati Purwandari ${ }^{2}$ \\ ${ }^{1,2}$ Universitas Muhammadiyah Magelang \\ triamardiana@ummgl.ac.id, ${ }^{2}$ septiyandari@ummgl.ac.id
}

\begin{abstract}
ABSTRAK
Tujuan dari penelitian ini adalah untuk mengetahui desain pembelajaran pada mata kuliah Pendidikan Matematika SD berbasis multiple intelligence, serta untuk mengetahui kelayakan desain pembelajaran pada mata kuliah Pendidikan Matematika SD berbasis multiple intelligence. Jenis penelitian ini merupakan penelitian pengembangan. Desain pengembangan pada penelitin ini mengacu pada teori Thiagarajan dengan menerapkan langkah 4D, yaitu, define, design, development, dan dissemination. Tahap define merupakan tahap yang berisi penetapan produk apa yang akan dikembangkan, beserta spesifikasinya. Tahap design merupakan pembuatan rancangan produk berdasarkan ketetapan di tahap define. Tahap development berisi pembuatan rancangan menjadi produk dan menguji validitas produk. Tahap dissemination berupa penyampaian hasil produk yang telah teruji untuk dimanfaatkan oleh pihak lain yang memiliki kepentingan serupa. Hasil dari penelitian ini berupa desain pembelajaran pada mata kuliah Pendidikan Matematika SD berbasis multiple intelligence. Kelayakan produk desain pembelajaran diuji oleh dua orang ahli yang telah menerapkan pembelajaran multiple intelligence. Kelayakan produk dari ahli diperoleh dengan hasil amat baik.
\end{abstract}

Kata kunci: multiple intelligence, interpersonal, naturalis, logika

\begin{abstract}
This research aimed at finding out a Multiple Intelligence based learning design of Mathematics Education, and finding out the validity of the learning design. It used the approach of Research and Development based on the theory proposed by Thiagarajan. It was conducted within 4 stages (define, design, development, and dissemination). Define was deciding the products to be developed and the requirements. Design was creating an initial draft of the product based on the result of define stage. Development was carried out by creating the product and conducting a test of validity. Dissemination was conducted by spreading information regarding the valid product to be used by other lecturers or institutions. The result of this research was a product of a Multiple Intelligence based learning design for Mathematics Education Subject. Two teachers that have been implementing a Multiple Intelligence theory were assigned to be validators. Then the product was said to have very good validity.
\end{abstract}

Keywords: multiple intelligence, interpersonal, naturalis, logic

\section{PENDAHULUAN}

Perguruan tinggi dengan sumber daya manusia yang sangat berkualitas akan mampu mengembangkan ilmu pengetahuan dan memberi cukup banyak sumbangan kepada pembangunan bangsa. Pada jenjang Perguruan Tinggi, dosen merupakan salah satu aspek sekaligus instrumen yang menentukan keberhasilan proses pendidikan, karena dosenlah yang bertindak sebagai pelaksanaan langsung dalam 


\section{Tria Mardiana1, Septiyati Purwandari²}

pembelajaran, selain itu sebagai motivator, fasilitator dan evaluator bagi peserta didik ketika memperoleh dan mengolah ilmu menjadi bermutu untuk dirinya dan bangsa (Ishaq, 2013). Dalam pembelajaran, hak paling asasi pembelajar adalah ketika pengajar dapat mengajar sesuai dengan gaya belajar serta modalitas belajar pembelajar (Said \& Budimanjaya, 2016). Pembelajar dalam hal ini dapat dikatakan sebagai seorang mahasiswa, sedangkan pengajar adalah seorang dosen.

Gaya belajar serta modalitas belajar merupakan representasi fungsi otak saat proses informasi berlangsung. DePorter dan Hernachi, mengklasifikasikan dua kategori yang utama tentang bagaimana seseorang belajar. Pertama, mengenai bagaimana seseorang dapat menyerap informasi dengan mudah (modalitas). Kedua, mengenai cara seseorang dalam mengatur serta mengolah informasi tersebut (dominasi otak). Pada intinya gaya belajar merupakan kombinasi serta bagaimana menyerap, lalu mengatur, dan selanjutnya mengolah informasi (Said \& Budimanjaya, 2016). Gaya belajar serta modalitas belajar menjadi aspek penting yang harus difasilitasi oleh seorang pengajar dalam melakukan kegiatan pembelajaran.

Gaya belajar berbeda dengan gaya mengajar. Gaya mengajar memeiliki pengertian berupa strategi transfer informasi yang diberikan oleh seorang pengajar kepada peserta didiknya. Sedangkan pengertian dari gaya belajar adalah bagaimana sebuah informasi dapat diterima secara baik oleh pembelajar. Berdasarkan hasil penelitian mendalam yang telah dilakukan oleh Dr. Howard Gardner, ternyata gaya belajar dari seorang pembelajar dapat tercermin melalui kecenderungan kecerdasan dari pembelajar itu sendiri (Chatib, 2015). Pada kegiatan perkuliahan yang terlaksana di Perguruan Tinggi, salah satu upaya yang dapat digunakan untuk memenuhi gaya belajar seorang mahasiswa yaitu dengan menerapkan pembelajaran aktif, atau active learning.

Pembelajaran aktif merupakan salah satu jenis pembelajaran yang sering diterapkan dalam kegiatan pembelajaran. Pembelajaran aktif (active learning) pada dasarnya adalah salah satu jenis dari pendekatan pembelajaran yang memiliki orientasi pada aktivitas peserta didik. Pembelajaran yang berorientasi pada kegiatan peserta didik memiliki suatu pengertian bahwa sistem pembelajaran telah menempatkan peserta didik sebagai subyek didik yang aktif dan telah 
memiliki kesiapan yang kuat untuk melaksanakan kegiatan belajar (Effendi, 2013). Namun demikian, ketika pelaksanaan penerapan dari strategi pembelajaran ini, terdapat suatu kekurangan. Salah satu kekurangan tersebut berupa pemilihan pada strategi yang hanya mendasarkan pada mahasiswa yang menjadi aktif ketika pembelajaran, namun tidak mendasarkan pada kecenderungan dari gaya belajar yang dimiliki oleh masing-masing mahasiswa. Sehingga, pemilihan dari strategi pembelajaran yang akan digunakan tidak jarang hanya membuat mahasiswa aktif dalam hal gerak saja dan esensi materi tidak tersampaikan dengan maksimal. Untuk itulah, perlu diperhatikan berbagai aspek dalam penentuan kualitas pembelajaran yang terbaik. Terlebih lagi ketika menentukan kualitas pembelajaran di tingkat Perguruan Tinggi yang berhadapan dengan para mahasiswa pembelajar tingkat usia dewasa.

Salah satu dari bentuk konsep kegiatan pembelajaran yang memperhatikan gaya belajar dari tiap-tiap orang adalah penerapan multiple intelligences. Multiple intelligences apabila diartikan ke dalam Bahasa Indonesia diterjemahkan sebagai kecerdasan majemuk atau kecerdasan ganda. Tokoh yang telah mencetuskan teori kecerdasan ganda adalah Howard Gardner yang berasal dari Havard University, Amerika Serikat. Howard Gardner merupakan psikolog yang memiliki aliran humanistic guru besar pendidikan pada Graduate School of Education. Tahun 1983 Howard Gardner menulis buku yang berjudul Frames of Mind: The Theory of Multiple Intelligences (Amir, 2013).

Melalui multiple intelligences dapat diketahui bahwa tipe kecerdesan seseorang berbeda-beda. Kecerdasan sendiri merupakan kemampuan memecahkan persoalan dan kreativitas yang membutuhkan banyak pengalaman serta pembiasaan dengan jam terbang relatif pada setiap orang (Chatib \& Said, 2014). Berdasarkan teori multiple intelligences, terdapat 8 jenis tipe kecerdasan. Kecerdasan-kecerdasan tersebut diantaranya adalah, linguistik, logis-matematis, spasial, kinestetitk, musik, interpersonal, intrapersonal, dan naturalis. Multiple intelligences merupakan pengenalan bagi para siswa untuk menentukan strategi mengajar yang sesuai dari pengajarnya (Chatib \& Said, 2014). Delapan kecerdasan ini memiliki identias masing-maisng serta karakteristik yang berbeda-beda sehingga menyebabkan gaya belajar yang berbeda-beda pula pada masing-masing individu. Salah satu cara yang 


\section{Tria Mardiana ${ }^{1}$, Septiyati Purwandari ${ }^{2}$}

dapat diupayakan adalah menentukan strategi mengajar yang dapat terwujud dengan tepat. Strategi mengajar yang tepat tentunya akan memfasilitasi secara maksimal kebutuhan-kebutuhan mahasiswa dalam belajar. Fasilitas belajar yang terpenuhi dalam jangka panjang, akan menunjang kualitas ilmu yang dimiliki dan kecakapan kompetensi-kompetensi yang dimiliki oleh mahasiswa. Tentunya hal yang dijabarkan ini akan menjadi bekal yang kuat ketika mahasiswa lulus nantinya dari Perguruan Tinggi.

Salah satu keberhasilan dalam pendidikan yang diselenggarakan suatu lembaga pendidikan, dapat diamati melalui kualitas lulusannya (Ariani, 2014). Sebagai suatu Perguruan Tinggi yang sangat memperhatikan kualitas lulusan, Program Studi Pendidikan Guru Sekolah Dasar di Universitas Muhammadiyah Magelang juga berupaya melalui berbagai strategi untuk membekali dan memaksimalkan kompetensi para lulusan. Salah satu hal utama yang dibekalkan kepada mahasiswa lulusan adalah berkenaan dengan konsep multiple intelligences. Multiple intelligences ini juga menjadi salah satu aspek dalam pencapaian visi misi Program Studi.

Konsep multiple intelligence karena menjadi salah satu kebutuhan utama dalam pembekalan mahasiswa, konsep ini juga diterapkan pada banyak bagian kegiatan perkuliahan dan juga penelitian dosen sebagai bentuk pencapaian visi misi Program Studi Pendidikan Guru Sekolah Dasar di Universitas Muhammadiyah Magelang. Salah satu kegiatan perkuliahan yang masih minim dalam penerapan multiple intelligence adalah pada desain pembelajaran di perkuliahan. Berdasarkan latar belakang yang telah diuraikan tersebut, penelitian ini dilaksanakan dengan tujuan untuk menghasilkan produk desain pembelajaran berbasis multiple intelligences beserta kelayakannya. Desain yang dibuat, dilaksanakan pada mata kuliah Pembelajaran Matematika SD.

\section{METODE PENELITIAN}

\section{Jenis Penelitian}

Jenis penelitian yang dilaksanakan pada penelitian ini berupa penelitian pengembangan. Penelitian ini mengembangkan perangkat pembelajaran untuk mata kuliah Pendidikan Matematika SD. Perangkat pembelajaran yang dikembangkan, 
merupakan perangkat pembelajaran yang diterapkan untuk perkuliahan selama 1 semester. Desain pengembangan pada penelitin ini mengacu pada teori Thiagarajan dengan menerapkan langkah 4D, yaitu, define, design, development, dan dissemination.Tahap define merupakan tahap yang berisi penetapan produk apa yang akan dikembangkan, beserta spesifikasinya. Tahap design merupakan pembuatan rancangan produk berdasarkan ketetapan di tahap define. Tahap development berisi pembuatan rancangan menjadi produk dan menguji validitas produk. Tahap dissemination berupa penyampaian hasil produk yang telah teruji untuk dimanfaatkan oleh pihak lain yang memiliki kepentingan serupa.

\section{Waktu dan Tempat Penelitian}

Penelitian dilakukan selama 5 bulan dari bulan Januari - Mei 2018. Penelitian dilakukan di lingkungan Program Studi Pendidikan Guru Sekolah Dasar, Fakultas Keguruan dan Ilmu Pendidikan, Universitas Muhammadiyah Magelang.

\section{Subjek Penelitian}

Penelitian ini menggunakan subjek penelitian mahasiswa Program Studi Pendidikan Guru Sekolah Dasar yang memperoleh mata kuliah Pendidikan Matematika SD, dengan sampel mahasiswa kelas paralel semester 3 angkatan 2016.

\section{Prosedur Penelitian}

Penelitian ini menggunakan langkah 4D dari Thiagarajan yaitu, define, design, development, dan dissemination. Secara rinci, prosedur penelitian yang dilaksanakan dalam pelaksanaan penelitian ini dapat diamati pada Tabel 1.

Tabel 1. Kegiatan Pelaksanaan Penelitian

\begin{tabular}{|c|c|c|c|}
\hline Alur Penelitian & Kegiatan Penelitian & $\begin{array}{l}\text { Pencapaian } \\
\text { Indikator }\end{array}$ & Output \\
\hline Define & $\begin{array}{l}\text { 1. Telaah Mengenai } \\
\text { Multiple Intelligences } \\
\text { 2. Penyusunan } \\
\text { instrumen Multiple } \\
\text { Intelligences Researh } \\
\text { 3. Tes Multiple } \\
\text { Intelligences Researh }\end{array}$ & $\begin{array}{l}\text { 1. Diperoleh Data } \\
\text { mengenai } \\
\text { Multiple } \\
\text { Intelligences } \\
\text { 2. Diperoleh } \\
\text { instrumen } \\
\text { Multiple }\end{array}$ & Data Teknis \\
\hline
\end{tabular}


Tria Mardiana1, Septiyati Purwandari²

\begin{tabular}{|c|c|c|c|}
\hline Alur Penelitian & Kegiatan Penelitian & $\begin{array}{c}\text { Pencapaian } \\
\text { Indikator }\end{array}$ & Output \\
\hline & $\begin{array}{l}\text { 4. Analisis hasil tes } \\
\text { Multiple Intelligences } \\
\text { Researh } \\
\text { 5. Klasifikasi } \\
\text { kecerdasan } \\
\text { mahasiswa } \\
\text { berdasarkan hasil } \\
\text { Multiple Intelligences } \\
\text { Researh }\end{array}$ & 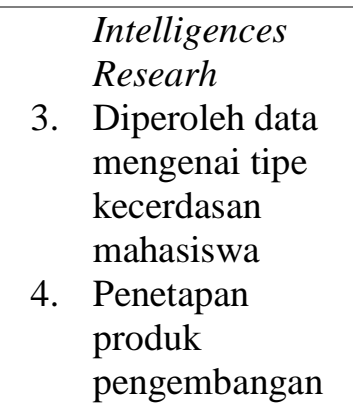 & \\
\hline Design & $\begin{array}{l}\text { Penyusunan desain } \\
\text { pembelajaran berbasis } \\
\text { Multiple Intelligences } \\
\text { berdasarkan hasil MIR }\end{array}$ & $\begin{array}{l}\text { Diperoleh rancangan } \\
\text { desain pembelajaran } \\
\text { berbasis Multiple } \\
\text { intelligences }\end{array}$ & $\begin{array}{l}\text { Rancangan } \\
\text { desain } \\
\text { pembelajaran } \\
\text { berbasis Multiple } \\
\text { intelligences }\end{array}$ \\
\hline Development & $\begin{array}{l}\text { 1. Pengembangan } \\
\text { produk } \\
\text { 2. Validasi produk pada } \\
\text { ahli } \\
\text { 3. Revisi produk } \\
\text { berdasarkan saran dari } \\
\text { ahli } \\
\text { 4. Produk jadi }\end{array}$ & $\begin{array}{l}\text { 1. Diperoleh data } \\
\text { produk } \\
\text { 2. Diperoleh hasil } \\
\text { validasi produk } \\
\text { 3. Diperoleh } \\
\text { produk revisi } \\
\text { hasil validasi } \\
\text { produk }\end{array}$ & $\begin{array}{l}\text { Desain } \\
\text { pembelajaran } \\
\text { berbasis Multiple } \\
\text { intelligences }\end{array}$ \\
\hline Dissemination & $\begin{array}{ll}\text { 1. } & \text { Melakukan } \\
\text { disseminasi pada } \\
\text { produk }\end{array}$ & $\begin{array}{l}\text { 1. } \begin{array}{l}\text { Terlaksananya } \\
\text { disseminasi } \\
\text { produk }\end{array} \\
\text { 2. } \begin{array}{l}\text { Diperolehnya } \\
\text { produk ahir }\end{array}\end{array}$ & $\begin{array}{l}\text { Produk ahir } \\
\text { desain } \\
\text { pembelajaran } \\
\text { berbasis Multiple } \\
\text { intelligences }\end{array}$ \\
\hline
\end{tabular}

\section{Teknik Pengumpulan Data}

Teknik pengumpulan data yang digunakan dalam penelitian ini adalah angket dan wawancara. Angket yang disusun digunakan ketika pelaksanaan proses tes analisis kecerdasan, serta ketika pelaksanaan proses validasi dengan menggunakan peran ahli. Angket untuk pelaksanakan tes analisis kecerdasan menggunakan Multiple Intelligence Research (MIR). Multiple Intelligence Research (MIR) merupakan suatu instrumen riset yang mampu memberikan berbagai deskripsi mengenai kecenderungan kecerdasan seseorang. Dari analisis terhadap kecenderungan kecerdasan tersebut melalui instrumen MIR, dapat disimpulkan gaya belajar terbaik bagi seseorang. Gaya belajar di sini diartikan dengan cara dan pola bagaimana sebuah informasi dapat dengan baik dan suskes diterima oleh otak seseorang (Chatib, 2015). Dalam penerapan pelaksanaan 
pembelajaran yang berbasis Multiple Intelligences, MIR menjadi tahapan wajib di awal pembelajaran sebagai langkah dalam memetakan gaya belajar yang sesuai.

\section{Teknik Analisis Data}

Teknik analisis data yang digunakan dalam penelitian ini menggunakan teknis analisis deskriptif.

\section{HASIL PENELITIAN DAN PEMBAHASAN}

Hasil yang diperoleh dari penelitian ini penjabarannya secara rinci megacu pada langkah 4D, yaitu define, design, development, dan dissemination.

\section{Define}

Pada proses define, hasil yang diperoleh berupa data mengenai Multiple Intelligences, instrumen Multiple Intelligence Research (MIR), data mengenai kecenderugan tipe kecerdasan mahasiswa, serta penetapan rancangan produk. Data yang telah diperoleh mengenai Multiple Intelligences dilakukan melalui berbagai kajian literatur. Kajian literatur yang dilakukan, diperoleh melalui referensi buku, artikel, dan berbagai data laporan penelitian terkini mengenai Multiple Intelligences.Kajian literatur yang diperoleh juga digunakan sebagai penguat data-data temuan dalam penelitian ini. Instrumen Multiple Intelligence Research (MIR) yang digunakan. Acuan pertanyaan yang digunakan untuk memperoleh hasil kecenderungan belajar melalui instrumen Multiple Intelligence Research (MIR) dapat diamati pada Tabel 2,

Tabel 2. Multiple Intelligence Research (MIR)

\begin{tabular}{|c|c|}
\hline $\begin{array}{c}\text { Jenis } \\
\text { Kecerdasan }\end{array}$ & Draf Pertanyaan Pada Angket Yang Diajukan \\
\hline \multirow{8}{*}{$\begin{array}{l}\text { Kecerdasan } \\
\text { Linguistik }\end{array}$} & Saya dapat merangkai banyak kata untuk menuangkan ide saya \\
\hline & Saya suka mempelajari bahasa dan bermain dengan kata \\
\hline & Saya menyukai teka teki silang dan permainan kata seperti Scrabble \\
\hline & Saya dapat mengingat sesuatu dengan baik apa yang orang lain katakan \\
\hline & Saya gemar mengikuti debat dan diskusi \\
\hline & Saya mudah menjelaskan sesuatu kepada orang lain \\
\hline & Saya suka menulis buku harian atau menulis cerita dan artikel \\
\hline & Saya sangat suka membaca \\
\hline
\end{tabular}


Tria Mardiana1, Septiyati Purwandari²

\begin{tabular}{|c|c|}
\hline $\begin{array}{c}\text { Jenis } \\
\text { Kecerdasan }\end{array}$ & Draf Pertanyaan Pada Angket Yang Diajukan \\
\hline \multirow[t]{6}{*}{$\begin{array}{l}\text { Kecerdasan } \\
\text { Logika }\end{array}$} & $\begin{array}{l}\text { Saya akan mampu belajar atau bekerja jika segala sesuatunya sudah } \\
\text { teratur }\end{array}$ \\
\hline & Saya menyukai matematika dan bermain dengan angka \\
\hline & Saya menyukai pertanyaan yang membutuhkan alasan \\
\hline & $\begin{array}{l}\text { Saya Saya akan mampu belajar atau bekerja sesuai dengan apa yang } \\
\text { sudah saya rencanakan }\end{array}$ \\
\hline & $\begin{array}{l}\text { Saya cepat menangkap sesuatu yang berkaitan dengan hubungan sebab } \\
\text { akibat }\end{array}$ \\
\hline & Saya selalu melakukan sesuatu satu tahap demi satu tahap \\
\hline \multirow{8}{*}{$\begin{array}{l}\text { Kecerdasan } \\
\text { Visual Spasial }\end{array}$} & Saya senang berdendang \\
\hline & Suasana hati saya berubah saat mendengar musik \\
\hline & Saya mudah mengikuti irama musik \\
\hline & Saya mudah mengenali jenis alat musik saat mendengarkan lagu \\
\hline & Saya suka mendengarkan musik dan lagu \\
\hline & Saya mudah mengenali nada \\
\hline & Saya suka mengikuti kegiatan yang berhubungan dengan musik \\
\hline & Saya mudah mengingat nada dan irama musik \\
\hline
\end{tabular}

\begin{tabular}{ll} 
Kecerdasan & Saya tidak menyukai polusi \\
\cline { 2 - 2 } Kinestetik & $\begin{array}{l}\text { Saya mengenali perbedaan dan persamaan antara tumbuhan dan segala } \\
\text { sesuatu tentang alam }\end{array}$ \\
\cline { 2 - 2 } & Saya memiliki perhatian yang besar dalam menjaga lingkungan \\
\hline & Saya menyukai acara TV tentang alam \\
\hline Saya menyukai kegiatan kerja bakti \\
\hline & Saya suka menanam dan merawat tanaman \\
\hline & $\begin{array}{l}\text { Saya suka memancing, menjelajah, dan melihat satwa } \\
\text { Ketika lulus, saya ingin memiliki pekerjaan yang berhubungan dengan } \\
\text { flora dan fauna }\end{array}$ \\
\hline
\end{tabular}

Kecerdasan Saya merasa tidak betah jika hanya duduk diam

Musikal Saya menyukai kegiatan olah raga

Saya memiliki rasa ingin tahu akan rasa, bentuk, dan tekstur benda

Saya memiliki koordinasi tubuh yang bagus

Saya suka membuat kerajinan tangan

Saya suka kegiatan yang melibatkan aktivitas fisik daripada duduk dan menonton

Saya memahami sesuatu dengan cara melakukannya

Saya sering berfikir ketika saya berjalan

\begin{tabular}{ll} 
Kecerdasan $\begin{array}{l}\text { Saya mengenali siapa diri saya } \\
\text { Interpersonal }\end{array}$ & Saya memiliki banyak sahabat dekat \\
\cline { 2 - 2 } & Saya memiliki argumen yang kuat terkait hal yang kontroversial \\
\cline { 2 - 2 } & Saya lebih cenderung bekerja secara mandiri \\
\hline & Saya tidak mudah terpengaruh dengan orang lain \\
& $\begin{array}{l}\text { Saya mampu memahami apa yang saya rasakan dan bagaimana } \\
\text { menyikapi suatu masalah }\end{array}$ \\
\cline { 2 - 2 } & Saya lebih suka membicarakan tentang nilai dan keyakinan
\end{tabular}




\begin{tabular}{|c|c|}
\hline $\begin{array}{c}\text { Jenis } \\
\text { Kecerdasan }\end{array}$ & Draf Pertanyaan Pada Angket Yang Diajukan \\
\hline & Saya lebih suka melakukan sesuatu dengan cara saya sendiri \\
\hline \multirow{9}{*}{$\begin{array}{l}\text { Kecerdasan } \\
\text { Intraperonal }\end{array}$} & Saya mampu mengenal warna dan kombinasinya \\
\hline & Saya menyukai permainan puzzle dan labirin \\
\hline & Saya lebih cepat memahami bagan dan peta \\
\hline & Saya mudah memahami denah dan petunjuk arah \\
\hline & Saya senang melihat adegan dalam film \\
\hline & Saya pengamat yang baik \\
\hline & Saya lebih sering melihat apa yang orang lain tidak lihat \\
\hline & Saya dapat menebak alur dalam permainan seperti catur, dll. \\
\hline & Saya dapat melihat secara visual di pikiran saya saat mengingat sesuatu \\
\hline \multirow{8}{*}{$\begin{array}{l}\text { Kecerdasan } \\
\text { Naturalis }\end{array}$} & Saya mampu memahami suasana hati dan perasaan orang lain \\
\hline & Saya suka berinteraksi dengan orang lain \\
\hline & Saya lebih menyukai olahraga beregu daripada tunggal \\
\hline & Saya mampu menangkap maksud pembicaraan orang lain \\
\hline & Saya lebih suka bekerjasama dengan orang lain \\
\hline & Saya suka mempelajari budaya lain \\
\hline & Saya menyukai acara yang didatangi banyak orang seperti pesta, dll \\
\hline & Saya suka bercerita dan berdiskusi dengan orang lain \\
\hline
\end{tabular}

Setiap mahasiswa akan diberikan instrumen dengan isi yang mengacu pada tabel 2. Setiap mahasiswa akan menjawab pertanyaan berdasarkan kondisi yang ada di dalam dirinya masing-masing. Intrumen MIR ini pada masing-masing item diberikan alternatif jawaban dengan penskoran berskala $1-5$. Masing-masing skor dari 1, 2, 3, 4, dan 5, memiliki makna yang berbeda-beda. Makna skor-skor tersebut adalah sebagai berikut,

Skor 1 - Tidak, pernyataan tersebut sama sekali tidak mencerminkan diri saya

Skor 2 - Pernyataan tersebut sedikit mendekati seperti diri saya

Skor 3 - Pernyataan tersebut agak mendekati seperti diri saya

Skor 4 - Pernyataan tersebut banyak mendekati seperti diri saya

Skor 5 - Ya, pernyataan tersebut mencerminkan diri saya

Ketika instrumen MIR telah digunakan untuk mengambil data, dilanjutkan dengan melakukan proses wawancara untuk proses konfirmasi sebagai penguat informasi yang diperoleh melalui pelaksanakan instrumen MIR pada mahasiswa. 
Melalui Multiple Intelligence Research (MIR), hasil identifikasi kecenderungan tipe kecerdasan mahasiswa dapat diamati pada Gambar 1.

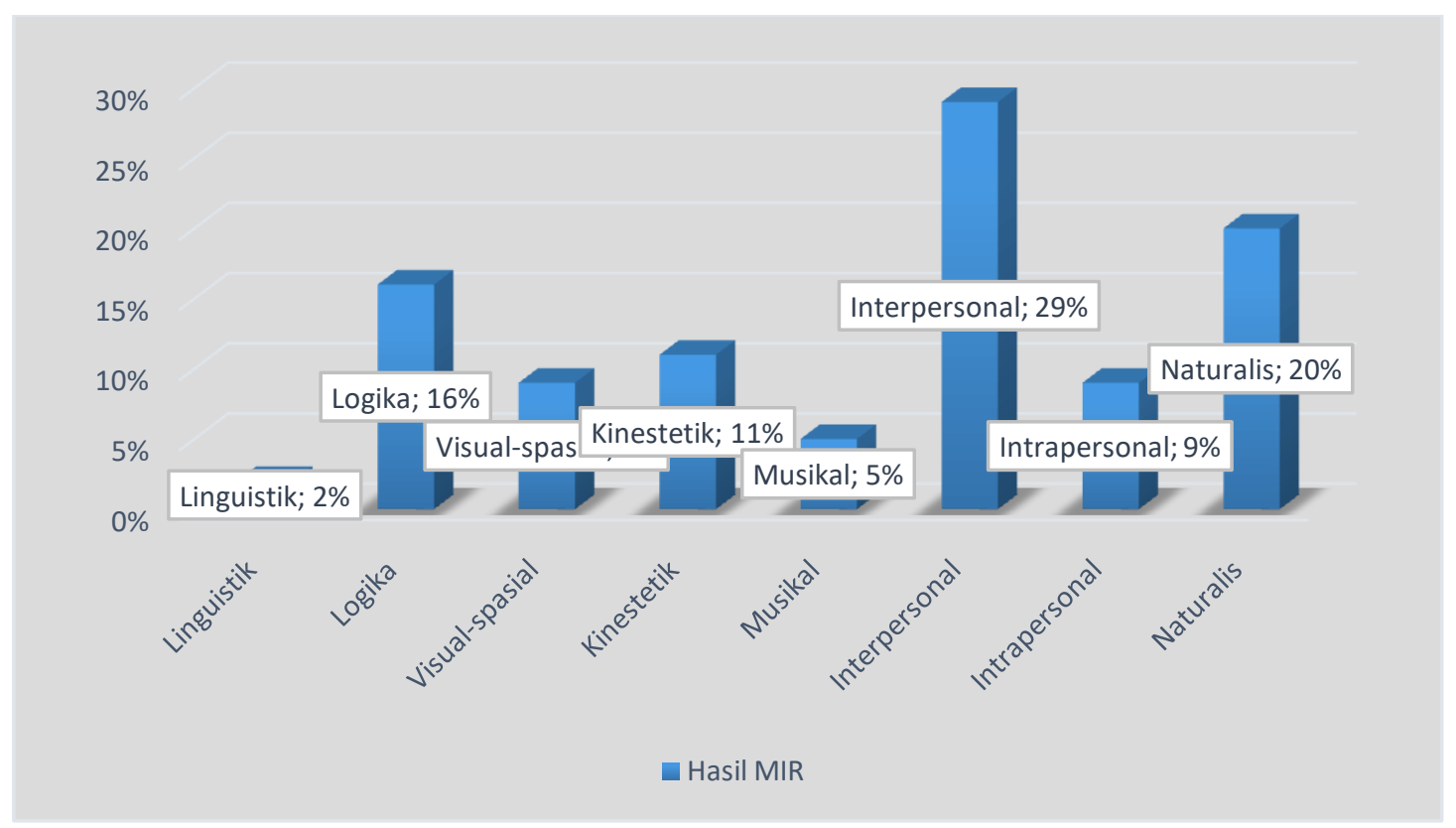

Gambar 1. Hasil Multiple Intelligence Research (MIR)

Pada diagram yang tersaji pada gambar dapat diamati bahwa hasil MIR pada mahasiswa beragam dan semua tipe kecerdasan terdapat nilai persentasenya. Kelompok tipe kecerdasan tertinggi adalah interpersonal, sedangkan kelompok tipe kecerdasan terendah adalah linguistik.

\section{Design}

Pada tahap design, peneliti melakukan proses perancangan desain pembelajaran berdasarkan hasil Multiple Intelligences Research (MIR) yang diperoleh. Desain pembelajaran diterapkan pada penerapn mata kuliah Pendidikan Matematika SD. Proses rancangan diawali dengan mengumpulkan dan memilih strategi-strategi menarik dari berbagai literatur. Strategi-strategi menarik yang dipilih merupakan hasil identifikasi dari 8 tipe kecerdasan yang terdapat pada Multiple Intelligences. Melalui identifikasi tersebut, diperoleh data mengenai kumpulan strategi-strategi menarik dari masing-masing tipe kecerdasan yang ada pada Multiple Intelligences. Pemilihan dan pengumpulan berbagai strategi menarik juga disesuaikan dengan karakter mahasiswa. Berdasarkan gambar 1, terdapat 3 tipe kecerdasan yang menonjol, yaitu kecerdasan naturalis, 
interpersonal, dan logika. Persentase masing-masing yaitu 16\%, 29\%, dan $20 \%$. Kecerdasan interpersonal memiliki persentase paling tinggi yaitu 29\%, sehingga pada setiap tatap muka perkuliahan, strategi pembelajaran yang mengacu pada kecerdasan interpersonal memiliki dominasi yang tinggi. Dominasi desain pembelajaran yang lain, terletak pada tipe kecerdasan naturalis dan logika berdasarkan pada data Gambar 1 yang diperoleh. Hal ini menjadi pilihan dan pertimbangan utama karena desain perkuliahan yang disusun benar-benar menyesuaikan dengan gaya belajar mahasiswa dan kebutuhan belajar mahasiswa.

\section{Development}

Pada proses development dilakukan pengembangan produk dan uji kelayakan produk. Pengembangan produk mengacu pada beberapa aspek yang menjadi dasar penentuan spesifikasi produk. Salah satu dasar utamanya adalah materi-materi yang ada dalam perkuliahan Pendidikan Matematika SD berdasarkan RPS yang digunakan pada perkuliahan. Materi perkuliahan Pendidikan Matematika SD terdiri dari 13 materi. Acuan materi-materi pada desain pengembangan produk mengacu pada Tabel 3.

Tabel 3. Materi Ajar Mata Kuliah Pendidikan Matematika SD
1. Teori Pembelajaran
7. Pecahan
2. Langkah dan Strategi
8. Geometri bangun datar
Pembelajaran Matematika SD
9. Luas dan Keliling bangun datar
3. Media Pembelajaran Matematika SD
10. Geometri bangun ruang
11. Volume bangun ruang
4. Permasalahan dan Solusi Pembelajaran Matematika SD
12. Hubungan antar satuan
5. Bilangan dan lambang bilangan
13. Pelaksanaan Pembelajaran
6. Operasi bilangan Matematika SD

Desain pembelajaran pada perkuliahan Pendidikan Matematika SD terdiri dari 2 bagian, yaitu bagian utama secara umum, serta bagian penjelas yang menggambarkan susunan serta konsep perkuliahan pada setiap tatap muka. Untuk bagian umum desain pembelajaran terdiri dari komponen-komponen berikut,

1. Nama Mata kuliah

2. Deskripsi mata kuliah 
3. Capaian perkuliahan yang diharapkan

4. Indikator capaian perkuliahan yang diharapkan

5. Tujuan umum perkuliahan

6. Materi-materi ajar perkuliahan

7. Hasil Multiple Intelligence Research (MIR) mahasiswa yang digunakan

8. Alokasi waktu

9. Gambaran kegiatan pembelajaran secara umum

10. Sumber Belajar

Kesepuluh komponen tersebut berfungsi sebagai identitas sekaligus penjelas perkuliahan Pendidikan Matematika SD yang akan dilaksanakan. Sedangkan pada setiap kali tatap muka perkuliahan berisi komponen berikut,

1. Materi yang akan diajarkan

2. Durasi atau waktu perkuliahan

3. Tipe kecerdasan yang difasilitasi dalam kegiatan pembelajaran

4. Indikator capaian perkuliahan

5. Media yang digunakan

6. Rincian pelaksanaan pembelajaran.

Pelaksanaan pembelajaran terdiri dari,

a. Alfa Zone

Kegiatan ini berupa pengkondisian mahasiswa agar pikiran mereka berada pada gelombang alfa. Menurut Munif Khatib kondisi ini merupakan kondisi otak yang pas dalam menerima informasi. Kegiatan alfa zone dapat diisi berupa kegiatan apersepsi namun terkait dengan materi yang akan diajarkan.

b. Pre Teach

Pre Teach merupakan kegiatan untuk membuka materi, dengan harapan agar mahasiswa terbangun rasa ingin tahu yang tinggi terhadap materi yang akan diajarkan.

c. Pembelajaran multi strategi

Multi strategi yang dimaksud di sini adalah kegiatan pembelajaran dilakukan dengan strategi-strategi yang memfasilitasi banyak tipe kecerdasan mahasiswa berdasarkan MIR. Pada setiap tatap muka tidak 
semua tipe kecerdasan difaslitasi pada hari yang sama, namun yang memiliki dominasi tinggi saja yang diterapkan setiap hari.

d. Konfirmasi

Tahap ini berupa pengecekan pemahaman mahasiswa terhadap materi.

e. Kesimpulan

Kesimpulan dilakukan secara bersama oleh dosen dan mahasiswa.

7. Durasi waktu secara detail pada masing-masing tahapan kegiatan pembelajaran

Produk yang telah dikembangkan kemudian divalidasi oleh ahli. Dalam penelitian ini digunakan 2 orang ahli untuk mengecek kelayakan produk desain perkuliahan yang dikembangkan. Proses validasi mengacu pada 7 aspek rencana pembelajaran yaitu,

1. Kelengkapan komponen rencana pembelajaran

2. Kesesuaian antar komponen rencana perkuliahan

3. Kelayakan tujuan pembelajaran

4. Perumusan tujuan pembelajaran

5. Pemilihan dan pengorganisasian materi ajar

6. Kelayakan kegiatan pembelajaran

7. Pemilihan sumber belajar

Masing-masing aspek memiliki item-item penguat untuk menjabarkan aspek tersebut. Total item yang dinilai oleh ahli adalah 43 item berdasarkan 7 aspek rencana pembelajaran tersebut. Pedoman penilaian pada lembar validasi instrumen adalah sebagai berikut,

1. Skor indikator keberhasilan

Keberhasilan penyusunan rencana pembelajaran, diberikan skor berdasarkan pertimbangan kualitas proses dan hasil yang diklasifikasikan sebagai berikut.

a. Skor tiap aspek: merupakan jumlah skor dari indikator

b. Kinerja komponen aspek $=\frac{\text { jumlah skor komponen yang diperoleh }}{\text { jumlah skor maksimum setiap komponen }}$

c. Skor Total: merupakan jumlah skor semua komponen (jumlah skor total $=$ 43) 


\section{Nilai Kinerja}

Nilai kinerja yang dijadikan sebagai pedoman adalah sebagai berikut,

a. Amat baik : skor $33-43$

b. Baik : skor $22-32$

c. Cukup : skor $11-21$

d. Kurang : skor $<10$

Proses validasi yang dilakukan pada ahli kemudian diperoleh saran perbaikan serta nilai kelayakan. Berdasarkan paparan data yang diperoleh, hasil validasi dari 2 orang ahli menunjukkan skor yang berbeda. Skor yang diperoleh dari 2 orang ahli adalah 39 dan 40. Skor tersebut masuk dalam kategori amat baik apabila menyesuaikan dengan pedoman penilaian. Berdasarkan uraian hasil tersebut, dapat diperoleh data bahwa desain pembelajaran berbasis Multiple Intelligences yang dikembangkan memiliki kelayakan dengan kategori amat baik berdasarkan validasi 2 orang ahli.

\section{Dissemination}

Pada tahap ini dilakukan proses diseminasi pada rekan dosen di lingkungan Program Studi Pendidikan Guru Sekolah Dasar, Fakultas Keguruan dan Ilmu Pendidikan, Universitas Muhammadiyah Magelang. Produk ahir juga tercipta di tahap ini, karena produk yang didiseminasikan merupakan produk ahir setelah dilakukan revisi berdasarkan saran perbaikan dari validator.

Teori kecerdasan multiple menegaskan bahwa untuk setiap orang memiliki beberapa level kecerdasan dan memiliki profil kecerdasan masing-masing (Maharani, 2015). Profil kecerdasan ini berupa 8 kecerdasan yang telah dicetuskan oleh Howar Gardner, yaitu linguitik, logis-matematis, spasial, kinestetik, musik, interpersonal, intrapersonal, dan naturalis. Kecerdasan linguistik merupakan suatu kemampuan berpikir dalam bentuk kata-kata, menggunakan bahasa untuk mengekspresikan, dan menghargai makna yang kompleks. Kecerdasan logismatematis merupakan kemampuan suatu dalam berhitung, mengukur, dan mempertimbangkan suatu proposisi dan hipotesis, serta menyelesaikan operasioperasi angka-angka. Kecerdasan spasial merupakan cara pandang dalam proyeksi tertentu dan kapasitas untuk berpikir dalam tiga cara dimensi. Kecerdasan ini 


\section{Pengembangan Desain Pembelajaran Mata Kuliah Pendidikan Matematika SD untuk Tipe}

Kecerdasan Interpersonal, Naturalis, dan Logika

memungkinkan seseorang untuk melakukan eksplorasi imajinasi, misalnya memodifikasi bayangan suatu objek dengan melakukan percobaan sederhana. Kecerdasan kinestetik merupakan kemampuan belajar lewat tindakan dan pengalaman melalui praktik langsung. Jenis kecerdasan ini lebih senang berada di lingkungan tempat dia bisa memahami sesuatu lewat pengalaman nyata.

Kemampuan bergerak di sekitar objek dan keterampilan-keterampilan fisik yang halus dan kemampuan mengolah tubuh ke dalam bentuk gerakan tertentu merupakan pola dasar kecerdasan kinestetik. Kecerdasan musik merupakan kemampuan seseorang yang punya sensitivitas pada pola titi nada, melodi, ritme, dan nada. Musik tidak hanya dipelajari secara auditori, tapi juga melibatkan semua fungsi pancaindra. Kecerdasan interpersonal merupakan kemampuan memahami dan berinteraksi dengan orang lain secara efektif. Kecerdasan interpersonal memungkinkan kita bisa memahami dan berkomunikasi dengan orang lain. Termasuk juga kemampuan membentuk, juga menjaga hubungan, serta mengetahui berbagai peran yang terdapat dala suatu kelompok. Kecerdasan intrapersonal merupakan kemampuan membuat persepsi yang akurat tentang diri sendiri dan menggunakan pengetahuan semacam itu dalam merencanakan dan mengarahkan kehidupan seseorang. Anak belajar melalui perasaan, nilai-nilai dan sikap. Kecerdasan naturalis merupakan jenis kecerdasan yang erat berhubungan dengan lingkungan, flora dan fauna, yang tidak hanya menyenangi alam untuk dinikmati keindahannya. Akan tetapi, sekaligus juga punya kepedulian untuk kelestarian alam tersebut (Chatib \& Said, 2014).

Penerapan teori kecerdasan tersebut, salah satunya dapat terpenuhi melalui strategi pembelajaran. Dalam strategi pembelajaran harus memperhatikan spesifikasi ataupun kualifikasi perubahan sikap dan prilaku seperti apakah yang diharapkan sebagai suatu hasil ketika aktivitas belajar mengajar itu berlangsung. Strategi yang dipakai pun juga harus tepat pada sasarannya. Pada umumnya penggunaan strategi sangat mempunyai pengaruh yang pokok terhadap keberhasilan proses pembelajaran. Tenaga didik seharusnya juga mengetahui apa tujuan dari pembelajaran tersebut jadi tujuan harus dirumuskan dengan begitu jelas. Sebab pengajaran yang tidak ada arah dan tujuan akan sulit di diproses dan dimengerti oleh peserta didik (Wahyudi \& Alafiah, 2016). 


\section{Tria Mardiana1, Septiyati Purwandari ${ }^{2}$}

Implementasi strategi pembelajaran yang menerapkan Multiple Intelligence dapat diamati melalui desain pembelajaran yang disusun. Pada penelitian ini telah disusun desain pembelajaran berbasis Multiple Intelligence. Berdasarkan teori Thiagarajan yang menerapkan langkah 4D dalam pengembangan produk, yaitu define, design, development, dan dissemination, penelitian ini telah dilaksnakan dan memperoleh hasil. Berdasarkan tujuan yang hendak dicapai dalam penelitian, pelaksanaan penelitian ini telah menghasilkan 2 item dalam menjawab tujuan. 2 item dalam penelitian ini berupa produk dan hasil uji kelayakan. Produk yang dihasilkan berupa desain pembelajaran pada mata kuliah pendidikan matematika SD dan hasil uji kelayakan berupa pernyataan tertulis dari ahli berdasarkan aspek penilaian produk.

Produk yang dikembangkan merupakan suatu produk yang berupaya memfasilitasi tipe-tipe kecerdasan mahasiswa untuk disesuaikan dengan gaya belajar yang dimiliki. Gaya belajar yang sesuai dengan mahasiswa mampu menciptakan ketertarikan dalam pembelajaran sehingga memunculkan motivasi belajar yang tinggi pula dalam pembelajaran. Komponen-komponen yang ada dalam produk pengembangan juga dibuat rinci sehingga memudahkan pemahaman dan penerapan pada proses perkuliahan. Berdasarkan hasil penilaian ahli, produk yang dikembangkan dalam penelitian ini juga memiliki kategori yang amat baik, yaitu skor dari ahli pertama sebersar 39, dan skor dari ahli kedua adalah 40. Skor tersebut diperoleh dari perhitungan yang tersaji pada pedoman penskoran dengan total skor apabila kualitasnya terpenuhi semua yaitu skor total 43. Skor yang telah memiliki kategori amat baik tersebut juga menjadi penegas bahwa produk yang dikembangkan memang memiliki kualitas kelayakan yang amat memenuhi kebutuhan pembelajaran mahasiswa.

\section{SIMPULAN}

Hasil dari penelitian ini berupa desain pembelajaran pada mata kuliah Pendidikan Matematika SD untuk tipe kecerdasan naturalis, interpersonal, dan logika. Kelayakan produk desain pembelajaran diuji oleh 2 orang ahli. Kelayakan produk dari ahli diperoleh dengan kategori hasil amat baik. 


\section{DAFTAR PUSTAKA}

Amir, A. (2013). Pembelajaran Matematika Dengan Menggunakan Kecerdasan Majemuk (Multiple Intelligences). Logaritma, I(1), 1-14.

Ariani, A. (2014). Hubungan Kecocokan Antara Tipe Kepribadian dan Model Lingkungan Belajar dengan Motivasi Belajar Pada Mahasiswa PGSD Universitas Achmad Yani Banjarmasin. Profesi Pendidikan Dasar, 1(1), 1-7.

Chatib, M. (2015). Sekolahnya Manusia (I). Bandung: Kaifa Learning.

Chatib, M., \& Said, A. (2014). Sekolah Anak-Anak Juara (III). Bandung: Kaifa Learning.

Effendi, M. (2013). Integrasi Pembelajaran Active Learning dan Internet-Based Learning dalam Meningkatkan Keaktifan dan Kreativitas Belajar. Jurnal Pendidikan Islam, 7(2), 283-308.

Ishaq. (2013). Desain Pengembangan Pembelajaran Berbasis Teknologi Informasi Dan Komunikasi (TIK) Pada Mata Kuliah Aplikasi Komputer. JPF, I(1), 7385.

Maharani, R. (2015). Model Pembelajaran Berbasis Teori Multiple Intelligences: Pembelajaran Kooperatif Dengan Pendekatan Saintifik Pada Pembelajaran Matematika. Jurnal Inovasi Pendidikan Dan Pembelajaran Matematika, 1(1), 11-24.

Said, A., \& Budimanjaya, A. (2016). 95 Strategi Mengajar Multiple Intelligences (IV). Jakarta: Kencana.

Wahyudi, D., \& Alafiah, T. (2016). Studi Penerapan Strategi Pembelajaran Berbasis Multiple Intelligences dalam Mata Pelajaran Pendidikan Agama Islam. Jurnal Kajian Pendidikan Islam, 8(2), 255-282. https://doi.org/10.18326/mudarrisa.v8i2. 